\title{
Composite scintillation panels and elements based on fine-grained granules of crushed crystals
}

\author{
V.Litichevskyi \\ Institute for Scintillation Materials, STC "Institute for Single Crystals", \\ National Academy of Sciences of Ukraine, \\ 60 Lenin Ave., 61001 Kharkiv, Ukraine
}

Received April 21, 2013

\begin{abstract}
The results of characteristics optimization of composite scintillation panels and elements for various applications have been presented. The dependences of the relative light yield intensity on particles size and thickness of the panel have been shown. The spatial resolution of the panels made of various fractions of the powder scintillator has been determined. The energy dependence on X-ray absorption efficiency of the scintillation panel based on ZnSe and the correspondence of effective thickness of the dispersed and single-crystal samples have been investigated. The results of the scintillation panels testing in the regime of registration of shadow images of biological and non-biological test objects under X-rays have been demonstrated. As a result of this work the composite scintillation material with improved properties of scintillation parameters homogeneity comparing with single-crystal ZnSe has been developed based on zinc selenide scintillator's powder. This material was used in production of the composite scintillation panels and elements for X-ray detection by multichannel photodetectors.
\end{abstract}

В работе представлены результаты оптимизации характеристик композитных сцинтилляционных панелей и элементов для различных областей применения. Приведена зависимость интенсивности относительного светового выхода от размера частиц и толщины панели. Определено пространственное разрешение панелей, изготовленных из различных фракций порошка сцинтиллятора. Получена энергетическая зависимость әффективности поглощения рентгеновского излучения сцинтилляционной панелью на основе ZnSe и установлено соответствие әффективных толщин дисперсного и монокристаллического образцов. Приведены результаты тестирования сцинтилляционных панелей при регистрации теневого изображения биологических и небиологических тест-объектов под рентгеновским излучением. В результате проведенных исследований разработан композитный сцинтилляционный материал на основе мелкокристаллического порошка селенида цинка, обладающий улучшенными свойствами равномерности сцинтилляционных параметров по сравнению с монокристаллами ZnSe. Материал применен при изготовлении сцинтилляционных панелей и элементов для регистрации рентгеновского излучения многоканальными фотодетекторами.

\section{Introduction}

In today's digital semiconductor radiography two major methods of scanning are implemented, such as scanning with fulllength matrix of X-ray detectors and scanning with use of one-dimension detector. Full-length matrix digital radiography is based on the large solid-state converting structure (matrix) with large enough area that is capable to create the digital image of scanning object with a high spatial resolution and good depth of contrast. This matrix is a two-dimensional surface divided into cells (pixels). Basically such X-ray detector consists of a matrix made from amor- 
phous silicon and a scintillation panel which is directly bonded to it. The X-ray detection occurs due to conversion by the scintillation panel of X-ray photon energy into the energy of radiation mainly from the visible spectrum and the subsequent detection of this light by semiconductor photodetectors. The same principle implemented in the onedimension detector scanners, the only difference relates to the detection system designed as line arrow of photodiodes which is mechanically moved relative to the scanning object. In both cases the quality of the images of the scanning object is mainly determined by parameters of the scintillation panel or element applied in the X-ray detector.

At the present time as a scintillation material for the manufacture of the scintillation panels, X-ray intensifying screens and other dispersed scintillators are widely used scintillation materials such as $\mathrm{Gd}_{2} \mathrm{O}_{2} \mathrm{~S}(\mathrm{~Tb})$, Csl:Na, Csl:TI, Nal:TI, ZnS:Cu, (Zn,Cd)S:Cu, (Zn,Cd)S:Ag, $\mathrm{CdWO}_{4}, \quad \mathrm{Bi}_{4} \mathrm{Ge}_{3} \mathrm{O}_{12}$ (BGO), $(\mathrm{Y}, \mathrm{Gd})_{2} \mathrm{O}_{3}: \mathrm{Eu}^{3+}(\mathrm{Pr}), \quad \mathrm{Gd}_{2} \mathrm{O}_{2} \mathrm{~S}: \operatorname{Pr}(\mathrm{Ce}, \mathrm{F})$ and others [1]. However, for the majority of the phosphors used a set of scintillation parameters is quite limited and does not meet all the requirements of modern detecting systems. This is relates to the technique of obtaining powdered phosphors and the methods of manufacturing of the scintillation panels on their base. To solve this problem we need to apply new scintillation materials with parameters that satisfy the requirements of the introscopic equipment. One such scintillators is zinc selenide (ZnSe).

Scintillator $\mathrm{ZnSe}$ relates to semiconductor materials of class of $A_{2} B_{6}$ group. It is widely used in scintillator-silicon photodiode systems for X-ray detectors of modern multichannel low energy means of visualization of hidden image (systems of non-destructive control, medical tomography, radiography) [2]. Crystals of zinc selenide possess a high luminescent efficiency (60 thousands photons/MeV) and short afterglow duration $(<0.05 \%$ after $6 \mathrm{~ms})$, which allows registration of the shadow image of biological objects in real time. Also an emission colour of this phosphor is orange-red, which makes it perfectly suited to detection by silicon semiconductor devices (Fig. 1). However, the production of scintillation panels from single-crystal zinc selenide is facing a number of difficulties. Firstly, ability of obtaining a large area crystalline samples of $\mathrm{ZnSe}$ is technologically limited, because with increasing of the

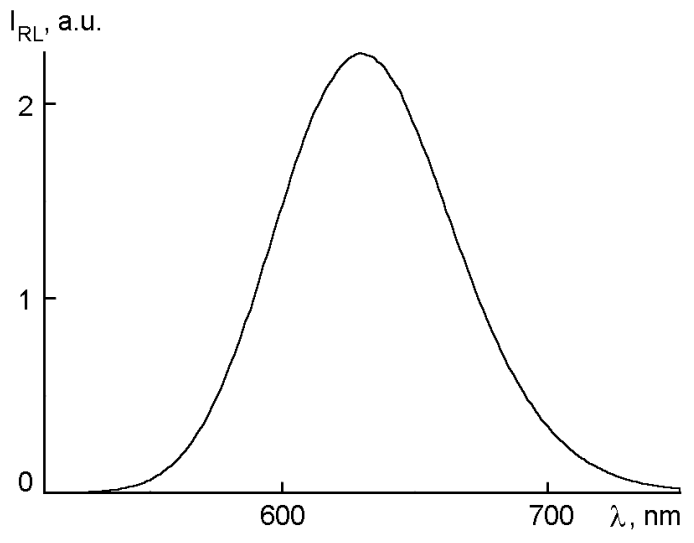

Fig. 1. Radioluminescence spectra of $\mathrm{ZnSe}$ standard scintillator.

crystal's size the homogeneity of luminescence is decreasing due to segregation of dopants in the crystal in the process of it growth. Secondly, synthesis of the scintillation powder of ZnSe without crystal growth step (various wet synthesis techniques, solid-phase sintering, etc.), which is more productive and efficient method for the scintillation phosphor manufacturing for the panels, does not show good results due to the high level of contamination of raw materials by different kinds of impurities.

The optimal solution of this problem is the use of zinc selenide-based fine-grained powders of crushed crystals. The starting material for scintillation powder obtaining passes a certain steps of selection and sorting in terms of intensity of the relative light output and duration of the afterglow. This technological step allows us precise control the functional properties of the material for scintillation panels. In the process of crystals crushing and the subsequent division by fractions we are performing a thorough homogenization of the scintillation powder and producing scintillation panels with high level of homogeneity (inhomogeneity of scintillation parameters does not exceed $2 \%$ ) [3]. Also manufacturing of the scintillation panels solves the problem of limited linear dimensions of single crystals because they have no such limitations.

For obtaining test object's image in modern introscopic devices the multi-channel photodetectors and large-format CCD are commonly in use. Scintillation elements based on single-crystals for these photodetectors must be separated into individual elements (pixels) to avoid redistribution of the intensity of light signals between the neighbor channels of the photodetector. In the case of composite scintillation panels 


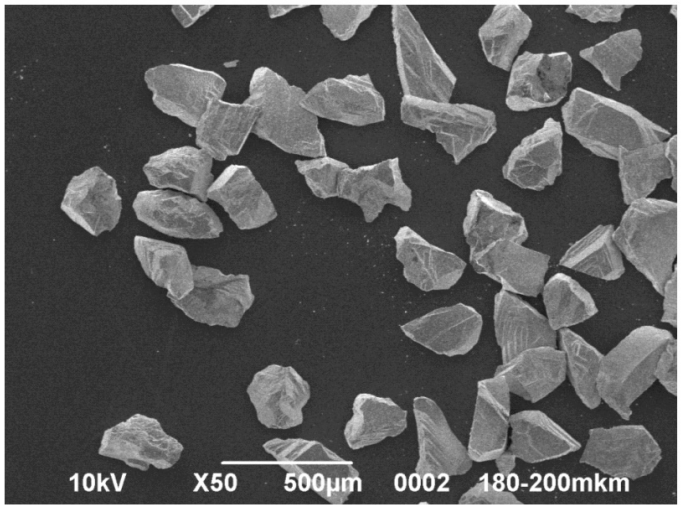

Fig. 2. Image of the crystalline powder of zinc selenide obtained by JSM-6390LV scanning electron microscope.

the scattering properties of the dispersed medium virtually eliminate redistribution of the intensity of light signals between the neighbor channels of the photodetector and localize the scintillation flashes. This eliminates the necessity of scintillation panel's separation into individual pixels. In some cases a decrease of photodetector's pixel size makes the use of composite panels the only available option, because the possibility of single-crystal element separation into individual pixels is technologically limited.

The aim of this work was obtaining the scintillation material in a form of composite scintillation panels and elements for X-ray registration on the base of $Z n S e$ scintillator with improved homogeneity of the scintillation parameters in comparison with the single crystal ZnSe. The results of the characteristics optimization of the composite scintillation panels and elements for various applications have been presented. The dependences of the relative light yield intensity on the particle size and thickness of the panel have been shown. The spatial resolution of the panels made of various fractions of the powder scintillator has been determined. The energy dependence on X-ray absorption efficiency of scintillation panel based on $\mathrm{ZnSe}$ and the correspondence of an effective thickness of dispersed and singlecrystal samples have been investigated. The results of the scintillation panels testing in the regime of registration of shadow images of biological and non-biological test objects under X-rays have been demonstrated.

\section{Experimental}

The objects of study were composite scintillation panels made of inorganic scintillator. The panels were produced in the form

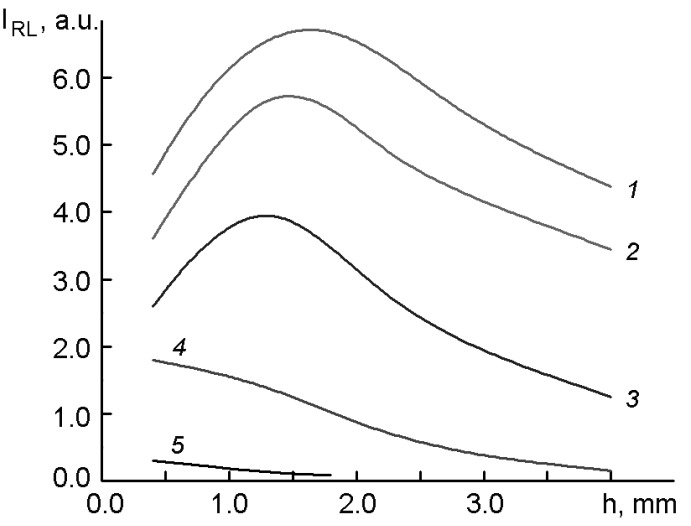

Fig. 3. Dependences of the light yield on the particle size and thickness of the polycrystalline dispersed samples of the scintillation panels based on $\mathrm{ZnSe}(\mathrm{Te})$. Curve 1 corresponds to the panel sample with a particles size of $200-600 \mu \mathrm{m}$, curve $2-$ particles size is $120-200 \mu \mathrm{m}$, curve $3-$ particles size is 40-120 $\mu \mathrm{m}$, curve $4-$ particles size is $25-$ $40 \mu \mathrm{m}$, curve $5-$ particles size is $1-25 \mu \mathrm{m}$.

of a layer of polycrystalline particles of irregular shape (Fig. 2) in the optical immersion medium - silicone rubber. The average degree of filling the composite elements by scintillator's powder was about 80 vol.\%. Thanks to the homogeneous distribution and dense packing of the particles in the scintillation element the homogeneity of their scintillation parameters was at a level about $98 \%$. Samples of the panels are made by pouring a mixture of powder scintillator and immersion medium in the container which covered with anti-adhesion material.

Measurements of X-ray light output value of the samples was carried out at $140 \mathrm{kV}, 30 \mathrm{mkA}$ and $20 \mathrm{~cm}$ distance from anode by using an installation for measurement of light yield and afterglow "Smiths Heimann AMS - 1".

Radioluminescence spectrum of the standard single-crystal scintillator ZnSe was obtained with use of a spectrometric complex KSVU-23 and X-ray source at REYES-I. X-ray tube voltage was $40 \mathrm{kV}$ and a current was $30 \mathrm{~mA}$ (Fig. 1). Scintillation signal registration was carried out by using a PMT-100 with the spectral sensitivity range from 160 to $850 \mathrm{~nm}$.

Determination of spatial resolution of scintillation panels was carried out by a known method with help of apparatus for $\mathrm{X}$-ray image registration (Fig. 5). As X-ray source was used an apparatus ISOVOLT Titan E X-ray Generator 160, and the spa- 


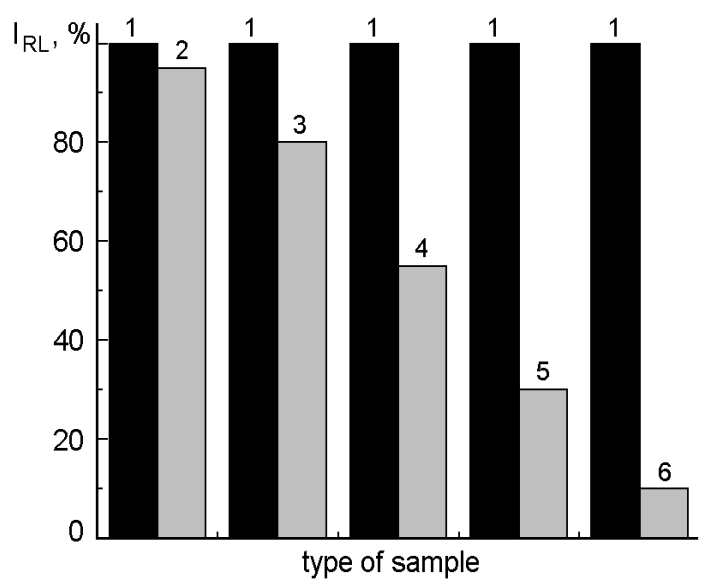

Fig. 4. Comparison of the light yield of the dispersed and crystalline scintillators based on $\mathrm{ZnSe}(\mathrm{Te})$ of identical dimension-type. 1 crystalline scintillator, 2 - dispersed scintillator (particles size is $200-600 \mu \mathrm{m}$ ), $3-$ dispersed scintillator (particles size is 120$200 \mu \mathrm{m}$ ), 4 - dispersed scintillator (particles size is $40-120 \mu \mathrm{m}), 5$ - dispersed scintillator (particles size is $25-40 \mu \mathrm{m}$ ), $6-$ dispersed scintillator (particles size is $1-25 \mu \mathrm{m}$ ).

tial resolution was determined by the standard test object EN 462-5 Duplex IQI.

$\mathrm{X}$-ray spectra were measured by X-123 spectrometer on the base of CdTe using an X-ray source ISOVOLT Titan E X-ray Generator 160 .

$\mathrm{ZnSe}(\mathrm{Al})$ powder image was obtained by usage of scanning electron microscope JSM6390LV (Fig. 2).

\section{Results and discussion}

For optimization of scintillation parameters of the scintillation panels the dependence of light output of the panels on the particle size of ZnSe scintillator and the thickness of the panel was determined (Fig. 3).

The dependence of ZnSe light output on the dispersion of the particles is determined by the degree of absorption of X-rays by the scintillator particles. The large particle absorbs the greater portion of X-rays, hence, the luminescence intensity increases with increasing the particle size. According to Fig. 3 particles with dispersion of 200$600 \mu \mathrm{m}$ have the highest intensity of luminescence. Thus, particles size reducing leads to decreasing the luminescence intensity of the particles and when you reach a certain size (about $30 \mu \mathrm{m}$ ) the luminescence becomes very low. This is due to the electron capture length in this material, and if it

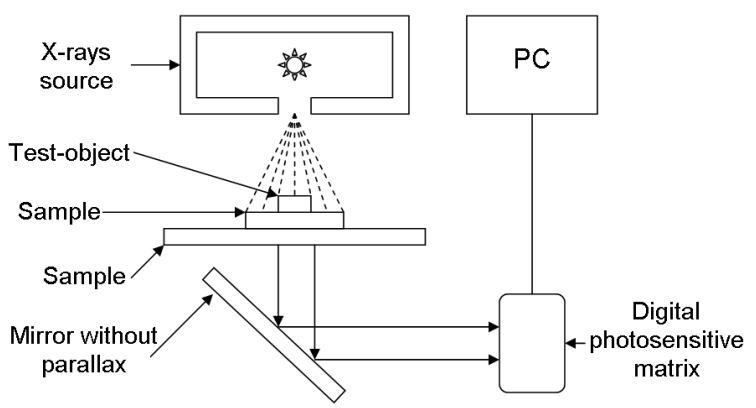

Fig. 5. Scheme of the apparatus for X-ray image registration and resolving power determination.

becomes longer than the size of the particles, then only a small fraction of X-ray radiation is absorbed in the material and induces the luminescence. Dissipative properties of the dispersed scintillator medium such as scattering and reabsorption of emitted luminescence photons also leads to reducing the luminescence with decrease of the particle size. The optimum thickness of the scintillation panels for maximum quantum yield for the samples with dispersion of particles of $40-120 \mu \mathrm{m}$ is $1-1.5 \mathrm{~mm}$, for dispersion $120-200 \mu \mathrm{m}$ is $1.3-1.8 \mathrm{~mm}$ and for dispersion $200-600 \mu \mathrm{m}$ is $1.5-2 \mathrm{~mm}$. When the thickness of the panel more then optimal the $\mathrm{X}$-ray radiation is absorbed in the upper layer of the sample and its intensity in the lower layers of the sample isn't sufficient to excite the maximum luminescence. Also scintillation photons from the upper layers do not reach the photodetector and released in the form of thermal energy. When the thickness of the panel is less than the optimal the maximum luminescence of the panel also isn't achieved because of lack of the scintillation material in the sample. For samples of the panels with smaller fractions of the scintillation material the optimal thickness of the screen becomes smaller.

Light output of dispersed and crystalline samples of scintillators based on $\mathrm{ZnSe}$ is presented in Fig. 4. The light output of the scintillation panels made of the coarse powder of zinc selenide with particles size in 200-600 $\mu \mathrm{m}$ becomes close to the crystalline sample (up to $95 \%$ of the light output of the crystal). With decreasing of particle size the light output is also decreasing. And for particles with a fineness of 120-200 $\mu \mathrm{m}$ reaches about $80 \%$, for particles with dispersion in 40-120 goes up to $55 \%$ and for dispersion in 25-40 $\mu \mathrm{m}$ goes up to $30 \%$ 


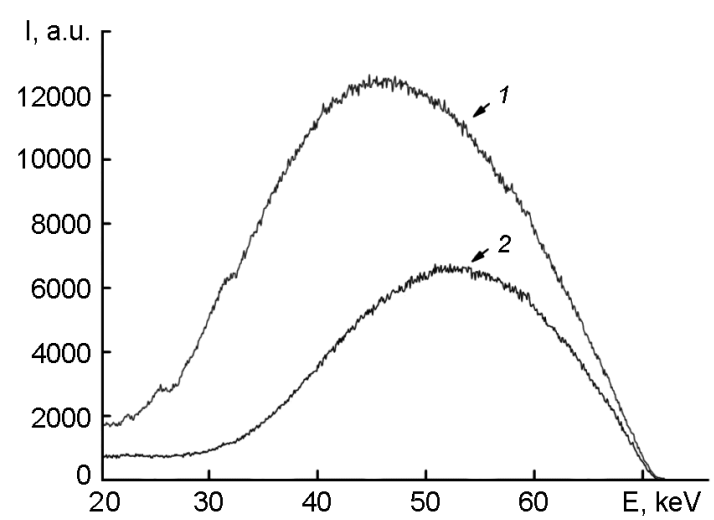

Fig. 6. X-ray spectra which were measured at the tube voltage $70 \mathrm{kV}$ and current $86 \mathrm{~mA}$. Curve 1 corresponds to the initial X-ray spectrum, curve 2 - spectrum after passing through the composite scintillator ZnSe of $1 \mathrm{~mm}$ thickness.

relative to the crystalline sample. The particles with dispersion less than $25 \mu \mathrm{m}$ are of no practical interest, due to extremely low light output which goes up to $10 \%$. Comparison of the light yield of the dispersed samples and the crystalline samples were made in the same conditions and with the samples of the same dimension-type.

For successful application of the scintillation panel in X-ray equipments it has to possess the number of necessary features such as satisfactory contrast sensitivity and resolving power in a wide dynamic range. Depending on the type of X-ray system the resolving power can vary by up to $20 \mathrm{lp} / \mathrm{mm}$ for the traditional film radiography, about $10 \mathrm{lp} / \mathrm{mm}$ for combined systems of film and intensifying screen and from 0.7 to $4-5 \mathrm{lp} / \mathrm{mm}$ for digital radiography $[4,5]$.

For spatial resolution dependences determination of the scintillation panels based on $\mathrm{ZnSe}$ on the size of the powder particles the measured sample panels were divided on three ranges of dispersion: the first $-40-$ $60 \mu \mathrm{m}$, the second $-80-100 \mu \mathrm{m}$, the third - 140-160 $\mu \mathrm{m}$ (experimental setup is shown in Fig. 5).

Scintillation panels made of the first range of dispersion possess the best resolving power - approximately 6-7 $\mathrm{lp} / \mathrm{mm}$. Such resolving power is achieved due to the small sample thickness $(0.1-0.3 \mathrm{~mm})$ and relatively small particle size of the scintillator $(40-60 \mu \mathrm{m})$ which form a dense layer of scintillation material and within this layer the scattering of scintillation flashes is minimal. The panels based on ZnSe powder
Table. Resolving power of the scintillation panels based on ZnSe

\begin{tabular}{|c|c|c|c||}
\hline $\begin{array}{c}\text { Size of ZnSe } \\
\text { particles in } \\
\text { the panel, } \mu \mathrm{m}\end{array}$ & $\begin{array}{c}\text { Thickness } \\
\text { of the } \\
\text { panel, mm }\end{array}$ & $\begin{array}{c}\text { Resolving } \\
\text { power of } \\
\text { the panel, } \\
\text { lp/mm }\end{array}$ & $\begin{array}{c}\text { X-ray } \\
\text { image }\end{array}$ \\
\hline $40-60$ & $0.1-0.3$ & $6-7$ & $=$ \\
\hline $80-100$ & $0.3-0.5$ & $4-5$ & $=$ \\
\hline $140-160$ & $0.5-1.5$ & $2-3$ & \\
\hline
\end{tabular}

with a particle size of $80-100 \mu \mathrm{m}$ have a lower resolving power $(4-5 \mathrm{lp} / \mathrm{mm})$. The resolving power of scintillation panels with powder dispersion in $140-160 \mu \mathrm{m}$ is $2-$ $3 \mathrm{lp} / \mathrm{mm}$ (Table). The deterioration of the resolving power of the scintillation panels with increasing the particles size can be explained by increasing the panel's transparency due to the enlargement of the particles and thus reduction of the number of scattering centers and light absorbing surface in the scintillator/immersion medium system. With increasing the panel's transparency the scattering cone of scintillation flashes also increases. The values of resolving power of the scintillation panels based on ZnSe obtained according to the optimized parameters of X-rays.

An important characteristic of the scintillation material is energy efficiency of $\mathrm{X}$-ray absorption which determines the dynamic range of the scintillator. For determination of the X-rays energy absorption efficiency of the scintillation element of $1 \mathrm{~mm}$ thick with powder particle size in 180$200 \mu \mathrm{m}$ two X-ray spectrum were taken: the original spectrum and the spectrum after passing the scintillation element (Fig. 6). The original X-ray spectrum was measured at X-ray tube voltage $70 \mathrm{kV}$ and current $86 \mathrm{~mA}$ with a filter - aluminum plate of $6 \mathrm{~mm}$ in thickness (curve 1 in Fig. 6). The calibration of spectrum was carried out by the X-ray tube's anode material (tungsten) lines of the characteristic radiation (tube voltage was $100 \mathrm{kV}$ and a current was $0.18 \mathrm{~mA}$, as the filter the copper plate of $2 \mathrm{~mm}$ thickness in was used). Curve 2 in Fig. 6 corresponds to the spectrum of the radiation transmitted through the composite scintillation element. 


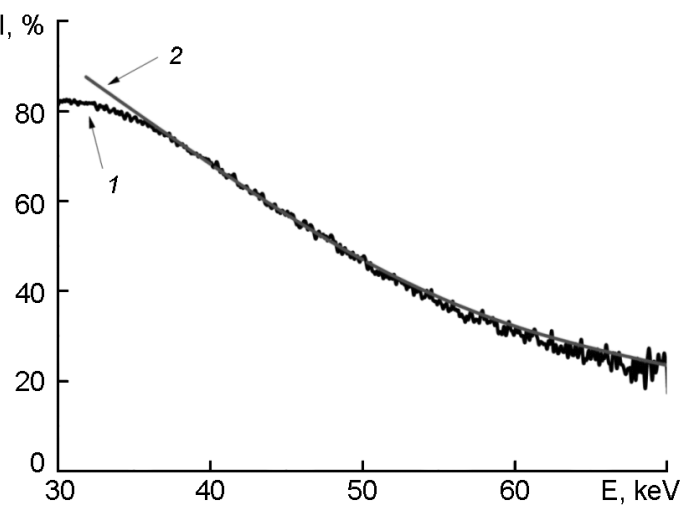

Fig. 7. Energy dependences of the X-ray absorption efficiency. Curve 1 corresponds to the absorption of X-rays in the composite scintillator ZnSe, curve 2 - calculated absorption efficiency of ZnSe single-crystal plate of $0.33 \mathrm{~mm}$ thickness.

The X-ray spectra analysis gave us the energy dependences of the X-ray absorption efficiency of the composite scintillator $\mathrm{ZnSe}$ (curve 1 in Fig. 7). The figure shows that zinc selenide effectively absorbs low-energy $\mathrm{X}$-rays, while increasing of the X-ray energy leads to the reducing of absorption efficiency. The theoretical curve 2 in Fig. 7 corresponds to the X-ray absorption efficiency of the single-crystal ZnSe plate $0.33 \mathrm{~mm}$ in thickness. It is in good agreement with the experimental curve 1 for the composite element ZnSe of $1 \mathrm{~mm}$ in thickness. This coincidence allows us to establish a correspondence between the X-ray absorption effective thicknesses of the single-crystal and composite element. Such a great difference in X-ray absorption efficiency of single-crystal sample and composite element is due to the fact that despite the high percentage of scintillator's powder in the immersion medium (about 80 vol. \%), the structure of composite element remains discrete. And because the particle size is sufficiently larger and has strongly irregular geometric shape the effective thickness of the composite element stands in the specified range. A good agreement between the calculated and experimental data allows us to compare the effective thicknesses of the X-ray absorption efficiency of the singlecrystal and composite samples.

In order to test the shadow image registering capabilities of the scintillation panels based on zinc selenide the X-rays images of organic and inorganic test objects such as piece of chicken wings and microchip were taken (Fig. 8 and Fig. 9). From the figures

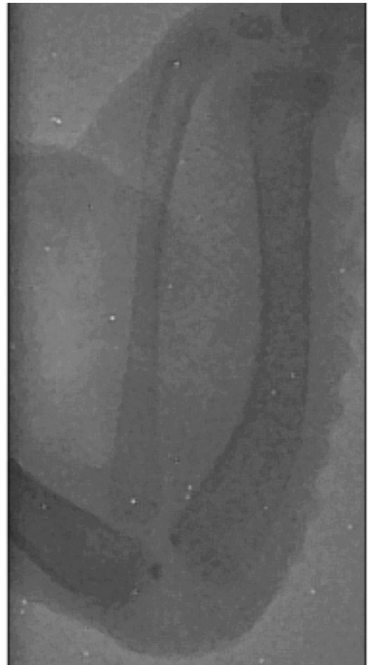

Fig. 8. X-ray image of the biological test object (chicken wing) obtained by using the scintillation panel based on ZnSe with dispersion of the scintillation particles of $80-$ $100 \mu \mathrm{m}$.

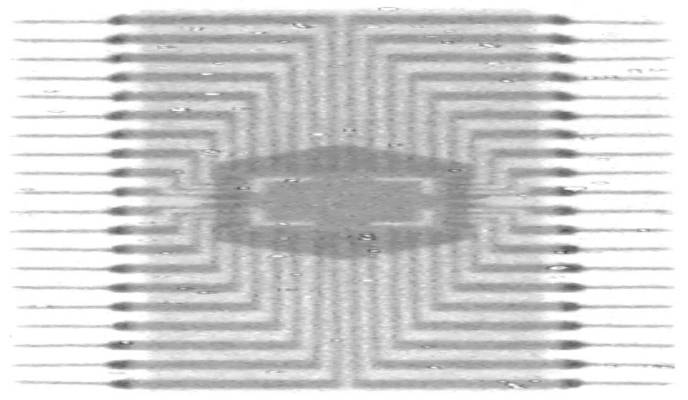

Fig. 9. X-ray image of the non-biological test object (microchip) obtained by using the scintillation panel based on ZnSe with dispersion of the scintillation particles of $80-100 \mu \mathrm{m}$.

it is clear that due to the high homogeneity of the scintillation parameters and high contrast sensitivity of the composite scintillation panels based on ZnSe the high level of image's sharpness and contrast depth was achieved.

\section{Conclusions}

Composite scintillation material based on zinc selenide powder that possesses improved homogeneity of scintillation parameters and has no limitations of linear dimensions in compare with single-crystal $\mathrm{ZnSe}$ has been developed. The interdependence of the relative light output on the thickness and particles size of the fine-grained scintillator's powders in scintillation panels has been defined. The dependencies of spatial resolution of the scintillation panels based on $\mathrm{ZnSe}$ on the thickness and particles size 
have been determined. The correspondence of spatial resolution values of the scintillation panels to the requirements and standards of the modern digital radiography has been demonstrated. It has been determined that the scintillation panel based on ZnSe scintillator's powder with a particle size of 25-100 $\mu \mathrm{m}$ and $0.1-0.3 \mathrm{~mm}$ in thickness are optimal for use in detectors for medical $\mathrm{X}$-ray imaging and tomography. Panels with a greater particles size (greater than $100 \mu \mathrm{m}$ and $0.5-1.5 \mathrm{~mm}$ in thickness) are perfectly suited for industrial flaw detection and security systems detectors. The basics of technology for composite scintillation panels and elements for X-ray detection based on fine-grained powders obtained by crushing the chalcogenide and oxide scintillators single-crystals has been developed.

Thanks to plasticity of the immersion medium around the scintillator's powder our composite scintillation panels and elements have increased resistance to mechani- cal stress, vibration and temperature changes in the range from $-50^{\circ} \mathrm{C}$ to $100^{\circ} \mathrm{C}$.

The developed composite scintillation material was applied in the experimental samples of scintillation panels and elements for multichannel X-ray detectors.

\section{References}

1. W.E.van Eijk Carel, Inorgan. Scintillators in Med. Imaging. Physics in Med. and Biol., No.47, 85 (2002).

2. L.Galchinetsky, V.Ryzhikov, N.Starzhinsky et al., Probl. Atom. Sci. and Technol.. Ser.: Phys. Radiat. Damage and Radiat. Mater. Sci., 88, 58 (2005).

3. V.Litichevskyi, S.Galkin, O.Lalaiants et al., Functional Materials, 18, 391 (2011).

4. A.Mikhailov, Means and Methods of Modern Roentgenography, Bel. Science, Minsk (2000).

5. A.Mikhailov, in: Possibilities and Limitations of Modern Methods of Medical Imaging, Conference Materials, BelMAPO, Minsk (2002), v.2, p.34.

\title{
Композитні сцинтиляційні панелі і елементи на основі дрібнокристалічних гранул подрібнених кристалів
}

\section{B.O.Літічевський}

\begin{abstract}
у роботі представлено результати оптимізації характеристик композитних сцинтиляційних панелей і елементів для різних галузей застосування. Наведено залежність інтенсивності відносного світлового виходу від розміру частинок і товщини панелі. Визначено просторову роздільну здатність панелей, виготовлених 3 різних фракцій порошку сцинтилятора. Отримано енергетичну залежність ефективності поглинання рентгенівського випромінювання сцинтиляційною панеллю на основі ZnSe, встановлено відповідність ефективних товщин дисперсного і монокристалічного зразків. Наведено результати тестування сцинтиляційних панелей при реєстрації тіньового зображення біологічних і небіологічних тест-об'єктів під рентгенівським випромінюванням. У результаті проведених досліджень розроблено композитний сцинтиляційний матеріал на основі дрібнокристалічного порошку селеніду цинку, що має поліпшені властивості рівномірності сцинтиляційних параметрів у порівнянні з монокристалами ZnSe. Матеріал застосований при виготовленні сцинтиляційних панелей та елементів для реєстрації рентгенівського випромінювання багатоканальними фотодетекторами.
\end{abstract}

